\title{
Fístula oral causada por pontas de esmalte - relato de caso
}

[a] Universidade Federal de Santa Maria (UFSM), Santa Maria, RS, Brasil

[b] Equident Odontologia Equina, Porto Alegre, RS, Brasil

*Autor correspondente

e-mail: izauravscherer@gmail.com

\section{Resumo}

Equídeos de trabalho que nunca tiveram qualquer tratamento odontológico mostram significativas pontas de esmalte em dentes molares, apesar de serem alimentados com uma dieta predominantemente à base de forragens. As pontas de esmalte são os distúrbios dentários mais comumente encontrados, e pelo menos $35 \%$ dos animais que apresentam essa alteração sofrem com úlceras na mucosa oral. Os procedimentos de nivelamento corretivo são frequentemente realizados para: aliviar o desconforto associado com lesões orais dos tecidos moles, causadas por pontas afiadas de esmalte; reduzir alongamentos dentários, que colocam stress sobre dentes e mandíbulas afetados; melhorar a mastigação e digestão dos alimentos; aliviar as tensões em dentes irregularmente desgastados; prevenir desconforto e melhorar o desempenho no cavalo que usa embocadura. 0 objetivo deste trabalho é relatar um caso de fístula oral decorrente do excesso de pontas de esmalte. Equino, fêmea, da raça Mangalarga Marchador, 7 anos, sob manejo extensivo, utilizada para reprodução como receptora e sem histórico de atendimento dentário prévio. No exame externo, o animal apresentou aumento de volume na face lateral direita, na região do dente Triadan 107, aproximadamente $10 \mathrm{~cm}$ caudal à comissura labial. Nesta assimetria havia uma fístula orocutânea. Ao exame intraoral, com equino sedado com $0,02 \mathrm{mg} / \mathrm{kg}$ detomidina IV, e uso de espéculo oral, fotóforo e espelho, foram observadas lacerações de bochecha severas do lado direito, ocasionadas pelas pontas excessivas de esmalte dentário dos molares. Como meio diagnóstico da origem fistular, o orifício cutâneo foi sondado com cateter e aplicado gel de clorexidina colorido como meio de contraste e antissepsia. Foi comprovada a relação da laceração de mucosa presente na mucosa oral na região do dente Triadan 107 com a fístula cutânea. Como tratamento, foi realizado o procedimento de odontoplastia e nivelamento das arcadas para correção das alterações oclusais e remoção das pontas a fim de proporcionar conforto ao animal. Complementarmente, foi feita limpeza 
e antissepsia da fístula e também curetagem dos seus bordos cutâneos. Trinta dias após o procedimento de nivelamento dental e odontoplastia, o equino obteve regressão completa da fístula. Casos como este reafirmam a importância de tratamento odontológico adequado, do tipo odontoplastia, esporadicamente ao longo da vida dos cavalos, aparando-se pontas de esmalte e corrigindo irregularidades na arcada, tanto na superfície oclusal, como nas superfícies vestibular, lingual e palatal. Por fim, este tipo de tratamento alivia a dor e favorece uma mastigação adequada.

Palavras-chave: Úlcera de bochecha. Fístula orocutânea. Pontas de esmalte. 